We should haye welcomed details of the measurements actually made on the different sections, for these are not given. The sections were of the length that could be measured in a day, and apparently between ten and twenty of them were comprised in the base, since they were from 1200 to 2400 feet in length; three measurements were made with different tapes, but we see no mention of each section being measured in both directions. A comparative table, setting forth all the measurements for each section, the temperatures, tensions employed, time occupied, \&c., as well as the character of the weather encountered, would have been of much interest, for at least on one day we are told that the wind made measurement impossible. A plan of the base site and a section of the line would also have been very useful to geodesists, who will look forward with interest to further publications of this character by the Ordnance Survey.

H. G. L.

\section{THE SHEFFIELD MEETING OF THE BRITISH ASSOCIATION.}

\section{Provisional Programme of Sections.}

A RRANGEMENTS for the programmes of the $A$ various sections of the British Association at the meeting to be held in Dundee on September 4-II are now approaching completion. By the courtesy of the Recorders of the sections we are able to give a forecast of the main subjects to be brought forward for discussion. Judging from this provisional statement, the scientific proceedings of the meeting promise to be of wide interest.

Section A (Mathematics and Physics). - The presidential address in Section $A$ will be delivered at Io o'clock on Thursday morning, September 5, by Prof. H. L. Callendar, F.R.S. The principal items arranged by the committee for subsequent days consist of three discussions. The first, to be held in conjunction with Section G (Engineering) is to be opened by Prof. J. A. Fleming, on the subject of the scientific theory and outstanding problems of wireless telegraphy. In his opening remarks, Prof. Fleming intends to put forward a large number of questions which still require an answer, and to make suggestions of his own towards supplying a complete answer. It is expected that Prof. A. E. Kennelley, Prof. A. G. Webster, and Prof. A. Sommerfeld will be able to attend, together with a large number of British investigators, and it is hoped that the meeting will form an exceptional opportunity for physicists, mathematicians, and engineers interested in this question to expound their own and criticise each other's views. The second discussion is on the atomic heat of solids, and is to be opened by Dr. F. A. Lindemann, of Berlin. Section B will collaborate in this discussion. There is probably no subject which combines in a greater degree speculation and experiment, and there is certainly none which can claim to be more the question of the present day, and it is intended that the discussion should familiarise English scientific men with the subject. The third is on series in spectra, with Prof. E. T. Whittaker as its opener. Dr. Whittaker is expected to deal with it chiefly from the dynamical point of view. Papers are coming in, but the programme is still incomplete. Those who desire to read papers are reminded of the new order NO. 2228 , VOL. 89] of the council that "no abstract shall appear in the annual report unless it is in print before the meeting," and no abstract can be so printed unless received during this month.

SeCtion B (Chemistry).-The proceedings of Section B should prove very attractive to followers of organic chemistry and its biological application. A sitting will be devoted to the carbohydrates and allied subjects, at which papers will be read by Prof. Irvine, Dr. A. Harden, Dr. S. Mills, and Dr. E. F. Armstrong. These should provide a valuable account of the progress which is being made in this field. A second sitting will be occupied by a discussion of a more general nature on the migration of groups: Dr. A. McKenzie will open this with a summarised account of the Walden rearrangement, and a second paper will be read by Prof. K. J. P. Orton. At a joint meeting with the Botanical Section, fixed for Friday, September 6, several important papers are promised of interest to agriculturists and botanists, as well as to chemists. Dr. J. V. Eyre will deal with the enzymes of flax and the variations of the flax plant with locality, and it is expected that some discussion will ensue as to the possibility of reviving the growth of flax in the British Isles. Mr. A. Compton, of the Pasteur Institute, will give an account of some of the recent French work on plant enzymes; Prof. F. Keeble and Dr. E. F. Armstrong will deal with the biochemistry of flower pigmentation. Other papers on organic chemistry are promised from Dr. R. H. Plimmer, Prof. C. R. Marshall, and Dr. J. K. Wood. A joint meeting will be held with Section A, when, following the discussion on specific heats, papers will be read by Dr. A. Holt, Dr. C. H. Desch, Prof. H. Marshall, and Mr. A. J. Berry.

Section C (GEology).-A large number of important papers has been promised for the meeting at Dundee, and these include several which will form the basis of discussions. Dr. Gordon, of the Geological Department of Edinburgh University, will read a paper on the fossil flora of the Pettycur Limestone, Fife, and its bearing on botanical evolution, which will be followed by a discussion, in which several leading members of the Botanical Section have promised to take part. A paper by Dr. J. S. Flett on the sequence of volcanic rocks in Scotland in relation to the Atlantic-Pacific classification of Suess, will also form the basis of a discussion, which, as several leading petrologists are expected to be present, should prove of considerable interest. Papers dealing with the recent discoveries of fossil remains in the Chert and Green Schist Series of the Highland border, north of Stonehaven, and in the neighbourhood of Aberfoyle, will be read by Dr. Campbell and Dr. T. J. Jehu, and the latter will also give an address on the geology of the country round Dundee and St. Andrews. Dr. Peach and Dr. Horne will contribute a joint paper on the Archæan rocks of the Island of Lewis. In all about twenty-five papers have been promised up to the present time. Excursions will take place during the meeting, including a visit to the famous fossil fish locality at Dura Den, where the quarry has been specially reopened, and at the close of the meeting a joint excursion with the Geologists' Association to Aberdeen and Arbroath has been arranged.

Section D (Zoology).-The president of the section is Dr. P. Chalmers Mitchell, F.R.S. There will be a joint discussion with Section $\mathrm{K}$ on the origin of life, opened by Prof. E. A. Minchin, and a joint discussion with Section I on physological conditions in aquatic animals. Prof. A. Pütter (Bonn) will speak upon this subject. Among the papers to be brought before the section are the following:--Life-history of a water beetle, Balfour Browne; note on some results of the 
Aberdeen University bird-migration inquiry, A. L. Thomson; metamorphosis and origin of the flat fishes, Dr. H. M. Kyle; on Scottish fisheries, I898-I9I2, Prof. MacIntosh, F.R.S.; life-history of Echinocardium, Prof. MacBride, F.R.S.; the survey of the fresh-water fauna of India now being conducted by the Indian Museum, Dr. Nelson Annandale; the fresh-water plankton of Lough Neagh: a seasonal study of the form variation in plankton organisms, Dr. W. J. Dakin; and the so-called speech in lower animals, Prof. R. J. Anderson. A collection of specimens and material of zoological interest will be on exhibition, and many zoologists have promised to contribute to it.

Section G (Engineering).-Prof. Barr, the president of this section, will probably take for the subject of his address the relation of the engineer to the public, and the responsibility which rests upon the engineering profession of carrying out works of public utility with due regard to the convenience and public health of the community, and a high standard of æsthetics. A joint discussion on wireless telegraphy with Section A will be opened by Dr. Fleming, and a discussion on the gas turbine will also take place with Dr. Dugald Clerk and Herr Holzwarth, of Mannheim, as the principal speakers. The committee on gaseous explosions will present a report on the turbulence of gases in engine cylinders and other matters. An interesting group of papers relating to naval architecture has been arranged for. Prof. Biles will deal with the rolling of ships; Prof. Gibson will describe his experiments on the suction between passing vessels; Mr. Axel Welin will read a paper on lifeboats for ocean-going steamers; and Prof. Henderson will consider various problems of propulsion in air and water. The navigation of the air will also be dealt with in a paper by Prof. Chatley on the control of aëroplanes. The road problem will be the subject of a paper by Sir John H. Macdonald, and a paper will be given by Mr. Wimperis on the acceleration of a motor-car. Arrangements have also been made for a group of papers relating to the materials of construction. $\mathrm{Mr}$. Haigh will describe a new machine for alternating load tests; Prof. Coker will read a paper on optical and electrical methods of determining the stress distribution in springs and other bodies; Prof. Hopkinson will give an account of some further experiments on the force of a blow, and Mr. Larard will show some kinematograph pictures of torsion tests. Papers on telephone circuits by Prof. Kennelly, alternating-current motors by Dr. Wall, and magnetic hysteresis by Prof. E. Wilson, have also been arranged for. Mr. R. S. Whipple will give an account of a new coal calorimeter, and Dr. Owens will describe some experiments on the effect of town air on the strength of building stones.

Section H (Anthropology).-The president, Prof. G. Elliot Smith, F.R.S., will read papers on early attempts at mummification in Egypt, and on the physical character of the ancient Egyptians of the second and third dynasties. A paper by Prof. G. A. Reisner will describe his excavations at the pyramids of Giza, and Prof. W. M. Flinders Petrie will give an account of early dynastic discoveries. Mention may also be made of papers by Mr. J. E. Quibell on excavations at the Sakkara Pyramids, and by Dr. F. Wood Jones on the ancient and modern Nubas. Mediterranean archæology will be covered by communications from the British School at Athens, including an account of recent excavations at Halos in northern Greece, by Messrs. A. J. B. Wace and M. S. Thompson, and a paper by Mr. T. E. Peet on megalithic monuments in the Mediterranean area. In British archæology, Mr. Marett will describe fresh evidence of palæolithic man in Jersey, Mr. Willoughby
Gardner the excavation of a hill fort near Abergele, and the Rev. O. Blundell his investigations of artificial islands in Scottish lochs. The ethnographical papers include Dr. W. H. R. Rivers's communications on conventionalism in primitive art and on navigation among primitive peoples, and Dr. C. S. Myers's description of Sarawak music.

Section I (Physiology). - This year will be distinguished by the number of well-known foreigners attending the section, more than twenty having accepted the invitation to be present. Apart from the address of the president of the section, Dr. Leonard Hill, F.R.S., and the reports of the various committees, the provisional progamme is given below. One day (Friday) is to be devoted to psychology. A discussion on the relation of mind to body, in which Prof. Latta, Sir T. S. Clouston, Dr. J. S. Haldane, and Dr. H. J. Watt will take part, will be one of the features of this day. The following papers will also be read: Dr. J. L. McIntyre, rôle of memory in animal behaviour; Mr. C. W. Valentine, on a suggested physiological theory of the horizontal vertical illusion; Mr. S. Dawson, on binocular and uniocular brightness discrimination. A discussion on the physiology of aquatic organisms with Section $D$ (Monday) will be opened by Prof. B. Moore; Prof. A. Pütter will also take part. On Tuesday a discussion will be held on animal nutrition (see agriculture). Prof. Heger, of Brussels, has promised a kinematograph demonstration, and the following papers will be read:-Prof. Leon Asher, on permeability of cells and a new method of vital staining; Prof. Max V. Frey, striated muscle under the action of veratria; Dr. E. Gley, le métabolisme du calcium chez l'animaux éthyroidés; Prof. Francis Gotch, colour perimetry in the darkadapted eye; Prof. A. Kossel, die guanidingruppe im proteinmolkül; Prof. J. J. R. Macleod, the relationship of the adrenal gland to the sugar content of the blood; Prof. C. R. Marshall, (I) the physiological action of quaternary methyl, ethyl, and methyl-ethyl ammonium compounds, (2) on coriamyortin and tutin, (3) the pharmacological action of nitric esters; Dr. R. R. Rentoul, the prevention of mental degeneracy; Dr. A. P. Waller, (I) Herbert Mayo and the facial nerves, (2) the electrocardiagram by the oscillograph.

Section K (Botany).-The main purpose of the address of the president, Prof. F. Keeble, will be to show that the Mendelian method used by students of genetics in investigating the inheritance of plant and animal characters is an invaluable adjunct to the physiologist. In illustration of the need of this cooperation between genetics and physiology an account will be given of the result of recent research in the origin of plant pigments. In the course of this account the work done on the subject by Prof. Keeble in collaboration with Dr. Armstrong, will be described. A morning sitting, will also be devoted to a joint meeting with Section B (Chemistry), during which kindred subjects will be discussed. The basis of the discussion will be the recent work of Dr. Eyre on enzymes, a summary of which will be given by $\mathrm{Mr}$. Compton. The discussion will be followed by papers on genetics and related subjects. A joint meeting has also been arranged with Section D (Zoology), at which the question of the origin of life will be introduced by Prof. E. A. Minchin, F.R.S. On Monday afternoon a semi-popular lecture will be given by Mr. Burkill on the botany of the Abor expedition. The lecturer will present the results of a study of the hills of eastern Himalaya, and his account will be illustrated by numerous lantern slides taken during the expedition. Papers have also been submitted dealing with various points related to the bacteria gymnosperms, ecology, physiology, and palæontology. NO. 2228 , VOL. 89] 
Section L (Education).--Prof. J. Adams, president of the section, has selected as the subject of his address, the possibility of objective standards in education. His aim is to estimate how far education has progressed in its way to be a science, and, with this in view, he proposes to examine the various developments of experimental work in psychology and pedagogy. In the section itself, the papers and discussions will centre chiefly in the subjects which for some years past have been arousing popular interest. Thus the chief matters already down for consideration are vocational training, the present position of mathematical teaching, the psychological processes involved in learning to read, write, and spell, with special reference to their practical bearings, leaving certificates, and the Scottish Education Department. In the discussion of vocational training, Miss Faithfull, of the Cheltenham Ladies' College; Miss Burstall, of the Manchester High School; Mr. J. L. Holland, director of education to the Northamptonshire County Council, Mr. J. W. Peck, clerk to the Edinburgh School Board; and Dr. Morgan, president of the Educational Institute of Scotland, have promised to talke part. The discussion on the present position of mathematical teaching is particularly opportune, as it was Prof. Perry's paper on "The teaching of Mathematics," read at the Glasgow meeting of the association, that. was responsible for developments that are now being criticised. Among those who have promised to take part are Sir Oliver Lodge, Prof. Perry, Dr. T. P. Nunn, Dr. Pinkerton, Mr. W. P. Milne, and Mr. W. D. Eggar. The discussion on the psychological processes involved in learning to read, write, and spell has been organised by the sectional committee on mental and physical factors involved in education. Papers will be read by Miss Foxley, Prof. Green, Dr. Rusk, Mr. F. Smith, Mr. Dumville, and it is hoped that Dr. C. S. Myers, Mr. Bompas Smith, Dr. Rivers, Mr. W. McDougall, Dr. Wm. Brown, and others will attend and take part in the discussion. The discussion on the Scottish Education Department is to be opened by Principal Sir James Donaldson, and Mr. J. Strong will deal with the Scotch leaving certificate. The reports to be presented to the section deal with the question of overlapping between school and university, the relation of school-books to eyesight, and tests for mental defect.

Section M (Agriculture).-The first meeting of the new section of the British Association-Section M (Agriculture)-promises to be of very special interest and importance to the great industry which it is designed to help by the promotion of science in this direction. The district round Dundee is famous for more than one branch of farming, which has been carried to a high degree of perfection, and the follow. ing programme shows that the local interests have been made a special feature. On Thursday, September 5 , the presidential address will be given by $\mathrm{Mr}$. T. H. Middleton. The remainder of the day will be devoted to papers dealing with milk. On Friday, September 6, Mr. R. H. Rew, of the Board of Agriculture, will read a paper on the sources of the nation's food supply, and Major P. G. Craigie, C.B., will contribute a paper on Scottish agricultural production - half a century's changes. A paper will also be contributed by Prof. J. Wilson, on a consideration of the profits realised from the usual field crops, more especially from temporary pasture. The remainder of the day will be devoted to two special papers on the agriculture of the district. On Monday, September 9, a joint meeting will be held with the Meteorological Department of Section A, the subject being the connection between meteorology and agriculture. Dr. W. N. Shaw, F.R.S., will read a paper on the pracNO. 2228 , VOL. 89$]$ tice of cultivation in relation to our knowledge of climate and weather, and Mr. A. Watt, secretary of the Scottish Meteorolngical Society, will open the discussion. Other general papers on this day will deal with the action of quicklime on soil, studies on nitrogen fixation, the rate of evolution of hydrocyanic acid from linseed, the influence of origin and topography on grass lands, and the problem of disease resistance. On Tuesday, September 1o, will be held a joint meeting with Section I (Physiology) on the important subject of animal nutrition. The discussion will be opened by Prof. F. G. Hoplkins, F.R.S., and continued by Prof. Leon Asher (Berne), Dr. E. P. Cathcart, Dr. C. Crowther, Dr. Leonard Hill, and Dr. Martin Flack, Prof. J. J. R. Macleod (U.S.A.), and Prof. T. B. Wood. This is the first time within recent years-if not the first time at all-when the practical feeder and the physiologist have met, and when the stores of knowledge and experience of the practical man have been drawn upon by the man of science.

\section{NOTES.}

WE are informed by the Royal Society that the Mackinnon studentships for the ensuing year have been awarded to Dr. H. M. Kyle (St. Andrews) for a. research on the metamorphosis and origin of the flat fishes, and to Mr. A. L. Hughes (Emmanuel College, Cambridge), for a research on the ionisation in mercury vapour produced by ultra-violet light.

THE John Harling fellowship for the encouragement of the study and research in physical science in the University of Manchester, has been awarded to Mr. H. G. J. Moseley, who was until recently an assistant lecturer and demonstrator in the department of physics in the University, and to Dr. T. S. Taylor, now instructor of physics in the University of Illinois.

The Franklin Institute of Philadelphia, $\mathrm{Pa}$., has awarded the Edward Longstreth medal of merit and diploma to Dr. Charles Baskerville, professor of chemistry and director of the laboratory at the city of New York, for his investigations on the chemistry of anæsthetics.

Among the victims of a terrible colliery accident at the Cadeby Pit, Yorkshire, on Tuesday, July 9, were three inspectors of mines, including $\mathrm{Mr}$. W. $\mathrm{H}$. Pickering, chief inspector for Yorkshire and the North Midlands. An explosion took place in the main pit early in the morning, and thirty men were killed by it. A rescue party was at work in the pit later in the day when several additional explosions occurred, and many other lives were lost, among those who suffered death while in the work of rescue being Mr. Pickering. Mr. Pickering was a Fellow of the Geological Society and the author of papers in the Transactions of the Institution of Mining Engineers and other societies. He was an authority on English and Indian coal mining, and founded the Mining and Geological Institute of India. His death will be deeply regretted by a wide circle of friends.

A communication of Prof. C. D. Perrine to the issue of Science of June 28 states that upon the recommendation of the Minister of Public Instruction the Argentine Congress has provided in its budget for I912 a 5 -ft. reflecting telescope for the National 